\title{
LINGUISTIC ANALYSIS OF NEWSPAPER TEXT
}

\section{Orazimbetova Z.K.}

Doctor Of Philology (Dsc), Professor, Department Of Journalism, Karakalpak State University, Uzbekistan

Mukhiyatdinova T.

Independent Researcher, Uzbekistan

\section{ABSTRACT}

This article describes the materials of the analytical genre of the newspaper, including the specific features of the genre of the article, its purpose, lexical and stylistic features.

KEYWORDS: - Journalism, style, language, type of text, genre, words, analytics, newspaper.

\section{INTRODUCTION}

The state of development of the literary language today is widely reflected in the print media. The preservation of the norms of the literary language, including spelling, lexical, grammatical and stylistic, are observed in the current newspaper language. At the same time, the language of the press has distinctive features peculiar only to it:

1. The language of the print media is one of the types of journalistic style of written literary language. However, in its external form it differs from other functional styles of the literary language.

2. The printed language is a freely functioning, energetically changing linguistic phenomenon associated with the changes taking place in society.

3. The language of the printed media, in addition to a number of related features in relation to the written literary language, also has some neutral properties. This can be seen in the variety of styles and forms of description in the materials published in the newspaper.

4. The language of print media has its own grammatical and stylistic expressiveness.

5. In both printed and written literary language, and in oral colloquial speech, there are characteristic features of the style of official documents, artistic literary and scientific styles.

6. The main article, materials of various content 
CURRENT RESEARCH JOURNAL OF PHILOLOGICAL SCIENCES 2(10): 82-

85, October 2021

DOI: https://doi.org/10.37547/philological-crjps-02-10-16

ISSN 2767-3758

(C)2021 Master Journals

sonem

8 Google

Accepted $26^{\text {th }}$ October, 2021 \& Published $31^{\text {th }}$ October, 2021

and character, chronicles, resolutions and telegrams and other information are published in the press. However, they are fundamentally different from each other in their stylistic, grammatical and features of the coverage of events. This feature enriches the structure and content of the language of print media, creates the basis for its diversity.

7. The main distinguishing feature of the language of the print media is the use of standard phrases and stamps in it.

8. If fictional material is given on the pages of print media, then its emotionality, expressiveness and imagery begin to increase, in this case it is considered a distinctive feature of the language of print media [1].

Therefore, first of all, the study and scientific research of the language of the printed media is of great importance for linguistics. In our state, the press is seen as a means of influencing the consciousness of the population, a powerful tool for educating the people in the spirit of the idea of national independence, as an organization uniting representatives of all nations and nationalities. And therefore, the language of the print media should be simple and understandable for all segments of the population and, as far as possible, avoid highflown words.

Of course, language is the national value of a people, which determines its unique features and spiritual world, it is not only a means of communication between people, but, at the same time, is considered an important tool for educating a person's personality. Every son of his people should make the unique possibilities of the language come true, take part in the development, enrichment and improvement of it and be responsible for his future and not remain indifferent in this matter. The Karakalpak language, while remaining the national literary language of our people, is at the same time the main means of forming high spirituality and culture, a messenger of pride in our achievements. This means that we must value and support him. If our task is to increase the authority of the literary language, then we must strictly follow its rules and norms.

In ensuring the place of the Karakalpak literary language as the state language, using it at a high cultural level in the print media, in the sociopolitical, spiritual, cultural and economic life of our republic, there is a close relationship between the development of the literary language with an increase in the standard of living of the people and the culture of communication between people with each other. friend.

Literary language is a delicate, sensitive instrument and, at the same time, it is a powerful instrument for influencing the minds and consciousness of people. Therefore, its rich features must be used in the right place. The answer to this question was the works of poets and writers, the speeches of scientists, teachers and journalists on radio, television, on the pages of newspapers and magazines. In their numerous speeches, disputes, meetings with labor collectives, students and students, they expressed their point of view on how to use the artistic word, grammatical forms of the language, new words and terms more correctly. Particular attention was paid to the language of the print media, because the language of the press is the beacon of the nation, the window of spirituality and enlightenment, the most important means of educating the younger generation. The implementation of the goals and objectives of promoting the possibilities of the language, designating its place and role in the future, strict observance of the laws and rules of the literary 
CURRENT RESEARCH JOURNAL OF PHILOLOGICAL SCIENCES 2(10): 82-

85, October 2021

DOI: https://doi.org/10.37547/philological-crjps-02-10-16

ISSN 2767-3758

(C)2021 Master Journals

Crossref do

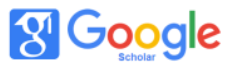

Accepted $26^{\text {th }}$ October, 2021 \& Published $31^{\text {th }}$ October, 2021

language, raising to a higher level of literacy, culture of speech and writing, great importance is attached to the media.

The Karakalpak literary language, strictly adhering to its laws and rules in writing and speaking, the Sami observe the norms of the literary language. Thus, we show deep respect for the native language, the language of the Karakalpak people. Mass media workers and journalists have a great responsibility in adhering to the norms of the literary language, because the language of the press is a mirror of the culture of the Karakalpak language. In the development of the rules of the literary language and strict adherence to them in practice, a special place is given to educational institutions, print media, radio and television. As we noted above, the print media have a great influence on the assimilation of the norms of the literary language, the observance of its rules in writing and speaking. Thus, the language of the press plays the role of a model in mastering the rules of the literary language. Therefore, the language of the press for all members of society is an example in improving their writing and speaking.

The development of life in society is impossible without contradictions and transformations in one area or another. Along with the abovementioned achievements in the modern print language, there are some drawbacks that create problems when using the literary language in print media. First of all, these are spelling, punctuation and grammatical errors, as well as stylistic flaws. Especially many such shortcomings are found in regional, departmental, and also in some republican newspapers. All these shortcomings cause a lag in the development of the culture of writing and speaking. Let's dwell on some of them:

1. Disadvantages encountered when replacing Russian and other borrowed words with Turkish, Karakalpak, and Persian-Arabic languages. As a result, words and terms previously unknown to the population entered our language, the language of the press. For example, instead of "autonomous republic" "mukhtar zhumgiriyat", "plane" - "otarba". However, in most cases, explanations were given about the fallacy of replacing one word with another. As a result, many of these words and terms never caught on in our language. However, in their work, journalists still use new words and terms from other languages. In some cases, they are used as variants of other words: programmist - dasturlewshi, sekretar - xatker, programma - dastur, bagdarlama, proekt joybar etc.

2. When using words in writing, there are both cases of repetition and cases of excesses. Such errors affect the content of the text and its perception. For example: oqıw, úyreniw, isenim, sarplanǵan kúsh, eldiń xalıqtı́n arı ushın umtılıwlar, sarplanǵan miynet kem-kemnen kózge kórine basladı.

3. Sometimes the use of incomprehensible words in a newspaper requires clarification. The use of such words in the newspaper is undesirable: baqlawshılar terakt aqıbetlerin túrlishe bayan etpekte. Feromon tutqısh qoyıp shıǵllıp, trixogramma jiberildi.

4. Incorrect or excessive use of synonyms: tiykarǵı nızamımızǵa tayanıp hám súyenip jumıs alıp barmaqtamız.

5. 5. Stylistic mistakes in the sentence. For example, an unnecessarily stretched text and because of this, the semantic connection between sentences is lost: Bizler apamız kórsetken gilemquraq kórpeshe, diywaldaǵı ilderilgen gilemapamızdıń 78ge shıqqandaǵ qol óneri ushın kerek bolar degen dámede naǵıslardıń atın sorap jazıp alıwǵa tırıstıq. 
CURRENT RESEARCH JOURNAL OF PHILOLOGICAL SCIENCES 2(10): 82-

85, October 2021

DOI: https://doi.org/10.37547/philological-crjps-02-10-16

ISSN 2767-3758

(C)2021 Master Journals

Crossief do) 8 " Google

Accepted $26^{\text {th }}$ October, 2021 \& Published $31^{\text {th }}$ October, 2021

6. The language of printing requires precision and specificity, each item must be named by its own name. In some cases, such mistakes are made in newspaper materials: Ózbekstan qosıqlar bayram tańlawının respublikalıq basqıshında bul jámáát 2-orındı iyeledi.

7. As a result of technical errors, the texts go out of print without a semantic link: Ómirińizdi qalayınsha alıp barıw, shólkemlestiriw, oypikirińizdi basqarıw siziń ... ńrzda! In this example, the syllable is not printed - qol (qolıńıda).

One should not remain indifferent to the errors listed above. Of course, if we treat these shortcomings with indifference, this will negatively affect the young generation of journalists, their growth as professionals, the general education of society and the development of the language of the print media. Among the above errors, the most common are the incorrect use of words, the composition of the text, the stylistic error of sentences. Unfortunately, for some newspapers, these phenomena are becoming commonplace, since every day there are more and more of them. Sometimes there are more than ten different types of errors in just one issue of the newspaper. This poses a big problem for the development of the language of print media.

The language of the print media is an integral part of one of the main heritage of our people the Karakalpak language, its mirror, an example of literacy and culture of speech. The aforementioned shortcomings are found more in some newspapers, in others less. Only a truly creative approach of a journalist to his duties, a sincere desire to fulfill the high mission of the profession can serve the development of the language of the print media. In our opinion, a great responsibility assigned to journalists is to create conditions under which the language of periodicals would always remain a model of correct writing and colloquial speech.

\section{REFERENCES}

1. Solganik G.Ya. About the language of the newspaper. - M.: 1968. - P.89.

2. Ayimbetov M. Experience of linguistic analysis of vocabulary and morphology of the Karakalpak publicistic text. Abstract of the thesis ... Candidate of Philology. - N.: Bilim, 1991. - P. 28.

3. Orazimbetova Z.K. Development of the language of the Karakalpak periodicals (Based on materials from the press of the 1924-1940s). Abstract of thesis. diss. ... Candidate of Philosophy - N.: 2006. - P.22.

4. Egorova T.V. Dictionary of foreign words of the modern Russian language. - M.: Adelant. 2014. - P. 157.

5. Rasuljanovna, I. N. (2020). The concept of "lacuna" in translation studies. Asian Journal of Multidimensional Research (AJMR), 9(4), 123-129. 